Southern Illinois University Carbondale OpenSIUC

Publications

Department of Geography and Environmental

Resources

$6-2010$

\title{
A Geographic Approach to Place and Natural Resource Use in Local Food Systems
}

Leslie Duram

Southern Illinois University Carbondale, duram@siu.edu

Lydia Oberholtzer

Pennsylvania State University

Follow this and additional works at: http://opensiuc.lib.siu.edu/gers_pubs

Copyright Cambridge University Press.

Published in Renewable Agriculture and Food Systems, Vol. 25 No. 2 (June 2010) at doi:10.1017/

S1742170510000104

\section{Recommended Citation}

Duram, Leslie and Oberholtzer, Lydia. "A Geographic Approach to Place and Natural Resource Use in Local Food Systems." (Jun 2010).

This Article is brought to you for free and open access by the Department of Geography and Environmental Resources at OpenSIUC. It has been accepted for inclusion in Publications by an authorized administrator of OpenSIUC. For more information, please contact opensiuc@lib.siu.edu. 


\title{
A geographic approach to place and natural resource use in local food systems
}

\author{
Leslie Duram $^{1, *}$ and Lydia Oberholtzer ${ }^{2}$ \\ ${ }^{1}$ Southern Illinois University, Carbondale, IL, USA. \\ ${ }^{2}$ The Pennsylvania State University, University Park, PA 16802, USA. \\ ${ }^{*}$ Corresponding author: duram@siu.edu
}

\begin{abstract}
This article illuminates the geographic concept of 'place' in local foods. Because the social aspects of local food have been more fully addressed in previous literature, this review focuses instead on the ecological aspects of farming and food. First, the literature on natural resource use in agriculture provides contextual understanding of water use, biodiversity, soils and agro-ecological methods. The complex relationship between climate change and agriculture is described and models assessing the impacts of climate change on agriculture are detailed. The geography of local food is specifically addressed by describing methods for assessing natural resource use in local food, including food miles, consumer transportation, scale and community, agricultural methods and diet. Finally, future research paths are suggested to provide a comprehensive evaluation of the environmental impact of local food. Such research would encompass the geography of local food through development of broader, more inclusive strategy, including the concept of the 'ecological appetite' of crops and foods, the union of both social and ecological aspects of resource use, the linkages between rural and urban producers and consumers and the inclusion of farmers' ecological knowledge. Overall, the geography of local food seeks to assess the where of food production and consumption, while incorporating key issues of how (agro-ecological methods benefiting the community) and what (locally appropriate crops).
\end{abstract}

Key words: local food systems, natural resource use, geography, food miles, energy use

\section{Introduction}

Scholars and advocates of local food systems in the US must be pleased with recent media and political attention to their issues. The 2009 inauguration of President Obama has translated into a sea of change for sustainable agriculture in the federal administration. Lady Michelle Obama planted an organic garden on the White House lawn and helped open a farmers' market just outside the White House grounds. The Secretary of Agriculture, Tom Vilsack, has initiated an organic garden on United States Department of Agriculture (USDA) grounds to help feed Washington, DC's homeless. Local foods have also taken a prominent place as Deputy Secretary of USDA, Kathleen Merrigan, launched a national 'Know Your Farmer, Know Your Food' campaign to recognize and increase support for local and regional food systems.

Change is evident in other important places, as well. For example, the American Medical Association (AMA) recently passed a resolution encouraging doctors to promote local and organic food to improve the health of their patients ${ }^{1}$. Although measuring the extent of local foods systems is difficult because of the wide array of practices that it encompasses, there are also real signs that farmers' markets and other direct-to-consumer forms of food marketing have increased significantly over the past decade ${ }^{2}$. There is a great deal of interest at the state governmental level as well, with 44 State Departments of Agriculture administering programs that label or promote state grown or processed foods ${ }^{3}$.

One topic of interest to this special issue is how local food systems interact with the use of natural resources, especially in relation to climate change. Researchers generally estimate that the food system uses between 12 and $20 \%$ of all US energy consumption ${ }^{4}$. Environmental claims, including the reduction of energy inputs and greenhouse gas emissions, of buying local are often cited as benefits of purchasing local foods ${ }^{5,6}$. Many believe that local food systems, with their reduced food miles, can save energy and reduce emissions and pollution. Thus far, research into local food systems and resource use has been contradictory at times, narrowly focused and inconclusive. Often missing from the discussion is the inherent complexity of place, natural resource use and scale. 
Food is a basic need that also represents perhaps the most fundamental linkage between people and nature. Geographers can play an important role in food systems analysis in that geography is concerned with the importance of place and is active at the intersection between humans and the environment. The importance of place, location and spatial variables are inherently geographic ${ }^{7}$. When a geographer ponders a topic, she may first pull out a map and then investigate spatial relationships in the analysis. The subfield within geography, which addresses society and environment, is a rich and important tradition. Early examples of geographers working at this intersection described human impacts on the environment, such as George Perkins Marsh's Man and Nature: Physical Geography as Modified by Human Action (1864). Today, this society and environment theme continues to be important in the geography discipline, and analysis of local food systems fits well into this theme. When approaching food and agricultural topics, a geographic approach is particularly relevant, as it encompasses multiple scales: local, regional, national and global. Thus, a geography of local food incorporates ecological and social variables at multiple levels of analysis.

Through a review of current literature on local food systems, with a particular emphasis on place and natural resource use, this article presents a framework of key topics on local food, outlines the relevant environmental variables in the geography of local food, and provides an analysis of future paths for the study of place in local food. There are important studies addressing social and ethical issues related to local food. Consider, for example, thought provoking articles on social justice ${ }^{8}$, equality ${ }^{9}$, human rights ${ }^{10}$ and food democracy ${ }^{11}$. Indeed, these topics are addressed at length in the literature elsewhere, so they are not the focus of this paper. Instead, by illuminating geographic themes within relevant natural resource literature, we see the evolving study of local food-how it is delineated today and how it may be analyzed in the future.

The first part of this paper examines the varying definitions of local in relation to food systems. Next, literature on natural resource use in agriculture provides a contextual understanding of water use, biodiversity, soils and agroecological methods. The complex relationship between climate change and agriculture is described and models assessing the impacts of climate change on agriculture are then detailed. Recent research methods to assess natural resource use in local food are reviewed; these methods address food miles, consumer transportation, scale and community, agricultural methods and diet. Finally, future research paths are suggested to provide a comprehensive evaluation of the environmental impact of local food.

\section{The 'Place' in Local Foods}

A stream of literature over the past decade has examined 'relocalizing' food systems and the development of local food systems or foodsheds ${ }^{12-16}$. These food systems are offered as alternatives to the increasing globalization and concentration of the agricultural system. In the USA, local food initiatives often develop out of a community action intended to make a statement in opposition to the conventional food system ${ }^{17-21}$ and sustainable or organic farming movements ${ }^{22}$. In Europe, local food is more often associated with rural economic development and food safety issues $^{23-27}$. Values embedded in these systems typically include environmental sustainability, social justice, organic production, support of local and regional farmers, as well as eating seasonally. Advocates claim that local food enhances the local economy by retaining food dollars through direct marketing in the community; increases food security and food safety as consumers know the producers of their food; and maintains ecological integrity through farming practices and distribution methods that reduce water pollution, soil degradation and fuel usage $e^{28-32}$.

Although local foods are increasingly gaining the public's attention, there is no clear geographical delineation for 'local'. Geography, however, can help us understand peoples' perceptions of local. For instance, the urban density on the East Coast may mean that local in Washington, DC is defined as within 100 miles from the city. If you live in Utah, however, the distances between urban areas may mean that 'local' can stretch hundreds of miles. There are a number of possible measurements of the term local, including a specific distance from production to consumption, state, county or regional boundaries, and if you consider comparing a product imported from another country, even national boundaries. Research has shown that consumers and farmers/businesses have varying ideas of how 'local' can be measured and interpreted ${ }^{33}$. In one study ${ }^{22}$, producers in three counties in the Northwest generally defined local as either within the county or adjacent county, within the state, or the northwest region, whereas a specific proximity (mileage or distance) was not an important indicator of 'local'. For consumers in these three counties, generally, proximity and within county or adjacent county were the most important indicators. Similar results from a study of Midwestern consumers and business ${ }^{34}$ found that consumers considered 'local' to be within a certain distance ( 25 or 100 miles) or within the state, while businesses were more likely to view the state or the entire Midwest region as 'local' boundaries. Ohio consumers did not distinguish between products 'produced nearby' and those 'produced in Ohio', 3 suggesting that the state level may be one geographic boundary for 'local', at least for Ohio consumers. For many in Iowa, the state boundary also marks the definition of local ${ }^{13}$. In a larger study $^{35}$, the vast majority defined 'local product' as either 'made or produced within 100 miles' $(50 \%)$ or 'made or produced in my state' $(37 \%)$.

\section{Considering Natural Resource Use in Food Systems}

Environmental factors in local food include biodiversity, water use, agro-ecological variables and energy use. 
Biodiversity is species richness ${ }^{36}$, which can be greatly impacted by production methods, with organic methods providing more biodiversity, particularly at the organism level $^{30,37}$. The diversity of species in agricultural landscapes is particularly important, as about one-third of the Earth's surface is in cropland and pasture. A second consideration in biodiversity is within the agricultural system itself: the genetic diversity of crops produced. For decades, research has called for agronomists, researchers and farmers to work together to maintain the diversity of crops and varieties being grown in agricultural systems ${ }^{38}$. More recent research indicates that local food systems can promote this cropping diversity. For example, a significant correlation was found between local sales and production of old varieties of apples; this may promote the preservation of heirloom varieties of crops ${ }^{39}$.

Modeling agricultural water use includes several broader concepts. For example, studies attempt to assess the 'virtual water' or amount of water needed to produce a $\operatorname{crop}^{40}$ or the national level of a 'water footprint' including import/ export, ground/surface and even climate variations that influence water usage ${ }^{41}$. In the USA, water is a resource both heavily used by agriculture and one that is energy intensive. Irrigated agriculture accounts for $80 \%$ of consumptive water used in the USA, with over $90 \%$ in some Western states ${ }^{42}$ and $15 \%$ of all energy expended for crop production ${ }^{43}$. While only $16 \%$ of cropland is irrigated, this acreage tallies almost half the value of all crops sold. Some commodities, such as corn, soybean and wheat in specific regions, have a higher share of operating costs from direct energy than in other regions, partly due to the additional fuel costs associated with irrigation ${ }^{44,45}$. Of course, irrigation management can lead to improved conservation, thus emphasizing the importance of farmer decisionmaking and attitudes in water usage $\mathrm{e}^{46,47}$.

The soil resource is obviously at the root of agriculture. On-farm agronomic variables determining crop production are soil type, soil health, precipitation, temperature and solar radiation ${ }^{48}$; these variables limit the crops that can be grown in a particular region, especially in a low-input system, in which crops must be ecologically appropriate to the region and local conditions ${ }^{49}$. Length of growing season and related techniques, such as greenhouses, that extend the growing season, impact planting and local land-use decisions ${ }^{50}$.

In the USA, agriculture as a whole is an energy-intensive sector $^{44}$. Direct energy consumption in the agricultural sector includes the use of gas, diesel, liquid petroleum, natural gas and electricity. Diesel fuel and gasoline are widely used for tillage, planting, transportation and harvesting. Electricity, liquid petroleum, gas and natural gas are used primarily in drying, irrigation, operation of livestock, poultry and dairy facilities, and on-farm processing and storage of perishable commodities. Indirect energy use involves agricultural inputs, such as nitrogen fertilizer, which consumes the most energy among production inputs because natural gas is the primary input $(70-90 \%$ of the cost of producing nitrogen fertilizer). Of the commodities, feed grain and wheat producers are particularly high energyconsumption commodities ${ }^{44}$. While hogs, dairy and cowcalf operations generally have relatively low direct energy costs, indirectly livestock production is energy intensive given that feed grains are a major input for the sector.

\section{Climate Change and Agriculture}

In addition to the natural resource factors that limit production and must be taken into consideration, broader-in fact global-ecological issues also influence the geography of local food. Climate change is rightfully at the forefront of current environmental thought, and is a critical issue for the discussion of local food systems. Agriculture plays an important role in climate change, but there are two sides to the coin. While climate change is impacted by many agricultural practices, climate change will also shape agriculture in most communities around the world. In fact, climate change impacts are occurring at a faster rate than previously considered likely, with increasing negative consequences for agriculture ${ }^{51}$. At the same time, agriculture acts as a small carbon sink in the USA, storing more carbon than released ${ }^{52}$ and, as such, US producers may benefit through policy changes meant to provide payments to farmers and ranchers for carbon offsets ${ }^{53}$ through changing tillage practices, reduction in methane and nitrous oxide emissions and tree planting (since forest lands act as a much greater carbon sink).

Agricultural production affects greenhouse gases (GHG) such as carbon dioxide, nitrous oxide and methane, and the cumulative effect of these gases are viewed in terms of net global warming potential. US agriculture accounts for a relatively small share (7\%) of total GHG emissions. However, it is a major source for two GHG, methane (accounting for 36\% of US methane emissions in 2007) and nitrous oxide $(73 \%)^{54}$. Agriculture influences the Earth's atmosphere in several ways, most notably through landuse change, fossil fuel use and agricultural practices. For instance, land taken out of forest or native grassland and put into agricultural production increases the amount of $\mathrm{CO}_{2}$ in the atmosphere. Agricultural soil management, including the application of nitrogen-based fertilizers, accounts for nearly half of all agricultural emissions ${ }^{52}$. Over 13 million tons of nitrogen, also a significant contributor to pollution in streams and waterbodies ${ }^{55}$, were applied to crops in 2007; this amount is increasing, due primarily to production of nitrogen-intensive demands of corn ${ }^{56}$. Livestock production demands large amounts of fossil-fuel-based grain production and results in high levels of methane ${ }^{57}$. Rice cultivation and burning of agricultural residues are also emission sources $^{52,54}$.

When comparing natural ecosystems to agricultural lands, mitigation of GHG can be achieved by removing lands from production. However, due to food supply demands, this land use change would only be feasible on a limited scale. Variations in production methods influence 
the level of future global warming. For instance, conventional tillage creates the most global warming potential, while no-till methods sequester some carbon in the soil but these are offset by increased nitrous oxide, and organic methods save some carbon dioxide by omitting synthetic fertilizers ${ }^{58}$. Indeed, nitrous oxide emissions from nitrogen fertilizer and methane emissions from meat and dairy production actually account for 55\% of agriculture's GHG contribution $^{59}$.

\section{Modeling Impacts of Climate Change on Agriculture}

Agricultural practices in the USA are likely to be greatly impacted by climate change, and climate models can help us study the potential impacts. At the global scale, climate models allow researchers to investigate trends in temperature and precipitation and their likely effects on agriculture. Drawing data from 23 global climate models from the Intergovernmental Panel on Climate Change (IPCC), researchers calculated the difference between historical and projected seasonally averaged temperatures ${ }^{60}$. Their results show that by 2100 , average growing season temperatures will exceed even the highest temperatures experienced during the 1900s, and that the geographic distribution of these temperatures are widespread. Whereas many people assume that tropical areas will be most affected, midlatitude agricultural regions in North America will very likely experience these extreme temperature increases, impacting agricultural methods and productivity. Horticultural crops (e.g. tomatoes, onions and fruits) are expected to be more sensitive to climate change than grain and oilseed crops. However, as climate variability increases and precipitation lessons, the latter will also experience higher rates of failure ${ }^{61}$. Although forage production is likely to extend in late fall and early spring, scientists expect significant impacts on livestock as rangeland and pastureland plant productivity and type shift, increased disease pressure on crops and domestic animals, reduced soil water availability early in the growing season and a lowered quality of forage.

More accurate and spatially specific climate change models are becoming possible due to increased computer capability; today even desktop computers can handle the data demands of some global models and they can be made available on the internet. Geographically, this is relevant to the recent viability of regional climate models. Yet, useful models at the local scale are still problematic, as global data do not yet provide the details needed for meaningful findings at the local scale ${ }^{62}$. Instead, researchers must downscale the global data, interpolate results and link to local data samples to develop specific examples of local changes that can be understood by the general population.

Regional studies of climate change also include models at the state level, most notable is the one of California ${ }^{63}$. This research shows significant increases in heat waves and extreme heat by 2100 (compared to 1961-1990 averages). The model predicts heat-related mortality to increase five to six times, making the outcomes of climate change very real. But harder to grasp are the interrelated ecological variables that will impact agriculture. With increasing temperatures, alpine forests and snowpack decline sharply. Combined with predicted decreases in precipitation, the impacts are reduced runoff and streamflow, which could fundamentally disrupt California's water rights system. Given that California is an agricultural area fundamental to the global distribution of food, these significant impacts are likely to have worldwide implications.

Regional variations in growing season length are another key consideration in agriculture, showing significant variation under different climate change scenarios. For example, one study ${ }^{64}$ showed that by 2100 , the Midwestern portion of the USA will have 32 more frost-free days compared to the average from 1961 to 2000 , significantly impacting the types of crops grown, prevalence of pests and other agronomic factors. Local and regional variations in climate stimulate further discussions about the current and future distribution of farming and food production.

\section{Assessing Natural Resource Use in Local Food}

Quantifying the impact of local food systems on resource use is a complex undertaking. Indeed, several diverse concepts must be included in this discussion: food miles, consumer transportation, scale and community, agricultural methods and diet.

\section{Food miles}

In the conventional food sector, it has been estimated that fresh produce travels an average of 1500 miles from farm to table ${ }^{4}$. The concept of 'food miles', or measuring the distance and impact of food between where it is grown and consumed, has gained popularity over the past decade, although it is more often employed in the European Union than in the US. The vast 'food miles' of the conventional system imply ecological degradation due to long-distance transportation and increased fuel usage. The geographic concept of food miles seems straightforward: fewer miles are better. Criticism of the food miles approach in its application to carbon accounting ${ }^{65,66}$ include that it shifts the argument away from sustainable agriculture production systems to a narrow focus on food distribution, transportation and the associated carbon created. To broaden the concept of food miles, another tool, Life Cycle Assessment (LCA) has been suggested by some ${ }^{66}$ as a way to include energy flows within all stages of the food chain. LCA, used in many industrial sectors to evaluate environmental impacts, tries to encompass all aspects of a production system, from beginning to end. Yet another approach is the Means-Ends Assessment that includes more subjective considerations about seasonality and locally appropriate crops $^{67}$. 
In its simplest form, though, food miles can be used to quantify some of the ecological attributes of one commodity. Measuring food miles, however, is always relative to place, so that a Californian-grown tomato may travel 1569 miles to reach Iowa consumers ${ }^{68}$, but only 100 miles to reach California consumers. Employing this tool, a $1 \mathrm{~kg}$ head of lettuce produced in California and shipped to New York requires $750 \mathrm{kcal}$ of energy for irrigation and $4140 \mathrm{kcal}$ of fuel for transportation in a refrigerated truck. In comparison, a $1 \mathrm{~kg}$ head of cabbage produced in New York requires just $400 \mathrm{kcal}^{69}$. Cabbage is chosen for the local product, compared to California lettuce, because of its greater nutrient value and longer storage capability. While the point is well taken - that food miles matter-at the same time, many consumers might find it difficult to substitute cabbage for lettuce in their leafy green salad in winter, bringing home the issue that localism of food in some regions requires sacrifices many may be unwilling to make. This is particularly true because consumers buy local food for many reasons other than simply reducing food miles ${ }^{70}$.

Intuitively we would believe that a fruit grown closer to home is less energy intensive, and this has been found to be the case for energy consumption and carbon dioxide emissions in at least one study ${ }^{67}$. However, seasonality is also an issue. Fruit that is available in September in the northern hemisphere must be held in cold storage for consumption the following April, when southern hemisphere fruit is in season. Still, a study of apples consumed in Germany in the springtime that had been refrigerated for 5 months, finds that locally produced German apples require $27 \%$ less energy than apples shipped in from New Zealand $^{71}$. Another study found that importation of Spanish field-grown lettuce into the UK during winter produced fewer GHG emissions than lettuce produced in UKprotected systems at that time ${ }^{72}$. Refrigerated transport to the UK was an important element of the global warming potential associated with Spanish lettuce (43\% of emissions); however, this was surpassed by the energy for heating that dominated the results in UK-protected cultivation (84\% of emissions). Studies from New Zealand indicate that energy use and $\mathrm{CO}_{2}$ emissions are actually lower when dairy, lamb and apples are produced in New Zealand and shipped to the UK, rather than produced in the UK itself ${ }^{73,74}$. A report by the United Kingdom's Department of Environment, Food and Rural Affairs (DEFRA) ${ }^{75}$ states that there is little evidence that local food has a lower ecological impact than globally sourced food, due to wide variations in the agricultural and environmental impacts of food grown in different eco-regions. For example, global sourcing could be the better environmental choice if local conditions are arid and large quantities of water were required for production of a specific crop.

\section{Consumer transportation}

Researchers have continued to expand the complexity of the tools used to assess food miles and energy consumption.
For instance, how a consumer shops for food has become part of the debate. Consumers who drive more than $7.4 \mathrm{~km}$ to purchase organic vegetables from a local farm shop are likely to emit more carbon emissions than consumers using home delivery from a large vegetable box-system ${ }^{65}$. Home delivery of locally sourced apples emit less carbon dioxide and take up less energy consumption than those picked up by the shopper driving only $2 \mathrm{~km}^{67}$. Another study showed that shoppers using a bicycle or walking to purchase food, or replacing a bus or home delivery for car shopping, were able to decrease the external environmental costs of the weekly UK food basket significantly ${ }^{76}$. In addition, locally produced (within $20 \mathrm{~km}$ ) food transported to retail outlets, as well as food produced nationally but transported primarily through a rail system, decrease environmental costs ${ }^{76}$.

\section{Scale and community}

The issue of scale has also been employed in a number of analyses. In the use of LCA on two food products, fruit juices and lamb meat ${ }^{77}$, the scale of the food business, and its efficiency of production and operations, was the most important variable in energy turnover. In both cases, the imported product (lamb imported from New Zealand and fruit juices from Brazil) required less energy than the same product from regional companies. The smaller size of the regional companies and farms impacted their ability to invest in energy-saving technologies, resulting in less efficient transportation systems and farming practices. Although limited to the two food items studied, the researchers suggest that there is an 'Ecology of Scale' at play here, with a minimum size of food business needed to obtain a good ecological quality of food. Other LCA food product analyses have addressed the issue of scale as well $^{78}$. But many more studies address the importance of place, social interdependence and community interaction in local food networks, which cannot be superseded by purely ecological comparisons of scale ${ }^{79-81}$.

\section{Agricultural methods}

Important to this discussion of these tools is that how food is produced may be as important as where food is produced $^{6,76}$. One recent study showed that GHG emissions from agriculture were concentrated in the production phase ( $83 \%$ of life-cycle GHG emissions), with transportation accounting for only $11 \%$ and final delivery from producer to retailer representing just $4 \%$ of the $\operatorname{total}^{59}$. Several studies indicated that organic production methods require significantly lower energy inputs than conventional production $^{30,82}$. Yet, research comparisons must consider specific crops, farming operations and post-harvest handling ${ }^{83}$.

\section{Diet}

Another factor in the assessment of natural resource use in our food is not just the how and where of our food, but the issue of what types of food are being produced, distributed 
and consumed. Dietary choices can significantly impact the environment, gaining complexity once the geographic aspect of food systems is added to the debate. At the most basic level, the fact that many Americans greatly exceed the FDA recommended 2000-2500 calories per day intake $^{84}$ exacerbates the impacts of food production, processing and transportation. Additionally, snacks, sweets and beverages have low nutritional values but require highenergy inputs for processing and distribution ${ }^{85}$. A vegetarian diet or equal caloric intake requires one-third less fossil fuel than a meat diet ${ }^{86}$. According to one study, changing to a vegetarian diet has a greater impact on lowering GHG emissions than buying local ${ }^{59}$. Other studies, however, stress exceptions. While the environmental burden of vegetarian foods is usually relatively low when production and processing are considered, if for instance, long-distance air transport, deep-freezing and some horticultural practices (such as heated greenhouse use) are added into the mixture of the vegetarian diet, the environmental burdens of these foods could exceed those for locally produced organic meat ${ }^{87}$. Even within the livestock category, there is wide variation: $1 \mathrm{~kg}$ of beef requires $13 \mathrm{~kg}$ of grain and $30 \mathrm{~kg}$ of forage ( $40 \mathrm{kcal}$ fossil fuel energy); while $1 \mathrm{~kg}$ of broiler chicken requires only $2.3 \mathrm{~kg}$ of grain. Organic pasture-fed beef, which is more often marketed by local producers, requires only $20 \mathrm{kcal}$ of energy, half that of conventional beef ${ }^{88}$. The geographic aspects of livestock production worldwide are complex ${ }^{89}$, and often different for developing and developed countries, creating varying environmental costs for consumers in different parts of the world.

\section{Discussion and Conclusion}

Geography is a starting point for the study of environmental impacts of local food systems, including the comparative resource use of local food systems, the impact of local food systems on climate change and the complex concept of energy use and food miles. One's location on the planet accounts for what fruits and vegetables and other food products will be available at what time of year, which in turns impacts one's use of natural resources.

At the same time, the study of the capacity of our individual 'places' to develop local food systems is just starting to emerge ${ }^{90}$. In fairly simple terms, Timmons et al. ${ }^{91}$ describe some of the capacity limits for local food systems in the USA. These calculations may provide an outside boundary of how far local foods can be expanded. However, they do not address the environmental consequences of maximizing local consumption in these places, and we have seen instances where local foods may not provide the most sustainable ecological outcome, according to certain measures.

Agriculture will need to adapt to immediate and future ecological conditions under the influence of climate change. Under moderate climate change, typical agricultural adaptations will likely be successful, but more severe climate change will require systemic transformation, such as significant diversification of production ${ }^{92}$. Further, our agricultural systems will need to be fully integrated into political, economic and social realms; thus, we will need geographic integration at local, regional, national and international levels in order to succeed in adaptation. Science, too, must take an interdisciplinary, inclusive approach to be relevant for all stakeholders and society as a whole ${ }^{91,93}$.

Indeed, the tools used so far to examine the ecological impact of our food are not comprehensive enough to look at the overall trade-offs. While there is value in gathering detailed data on agro-ecological topics, research must step beyond narrow approaches (e.g., food miles that only measure $\mathrm{CO}_{2}$ emissions) and integrate the issue of GHG emissions into the broader ecology of food production. Local food may be one way to address the issues of energy use and transportation of food, two concerns that will become more pressing as the ramifications of climate change become increasingly apparent. Thus, realistic ecological studies of local food studies must integrate crop choice, production methods, energy demands, GHG emissions, transportation and post-harvest production. With continued data collection and integrated analysis of these multi-faceted variables, we can gain a comprehensive understanding of the value of 'place' in the ecology of local food under changing environmental conditions.

Documentation on the geography of local food is rich and growing. The social advantages of local food have been more clearly articulated in the literature thus far. The ecological advantages of local food, while substantiated by some studies, demand additional attention. Linking the ecological factors with the significant literature on social aspects of local food will provide an even fuller understanding of our food system. This will lead to a better understanding of options that agriculture can contribute to mediate climate change.

We must also draw on the society-environment tradition of geography and incorporate both ecological and social aspects into the assessments of local food. It is possible, for example, that the human context of local food also displays interrelationships similar to the ecological systems thinking - resilient communities, sustainability and holism $^{94}$. Farmers' ecological understanding may be tapped to inform community actions related to food consumption $^{20}$. Further, production methods, such as organic production, may provide more sustainable ecological and socio-economic conditions for developing local food systems to counter globalization ${ }^{79}$.

The geographical value of local food is obvious: there are numerous advantages to producing and consuming food close to home, but there are many aspects of local food systems that still need to be studied to ensure food system sustainability. As we look to the future, research on local food must build on its successful roots and blossom into new integrated approaches and inclusive topics ${ }^{95}$. Specifically, research paths could include:

1. Developing an understanding of our 'ecological appetite' by strengthening the narrow definition of food miles 
to include natural resource use in agricultural production, processing and distribution. Essentially, creating a food item's contribution to global environmental change. One impact may be that consumers could be informed of the impacts of specific foods; further research that considers consumer labeling of these attributes is needed.

2. Incorporating social and ecological dimensions of local food, using a systems approach where personal (organism) networks and community resilience and interdependence are measured and included in food system research and assessment.

3. Considering linkages between urban issues and rural land uses related to local food. For example, the importance of place in food is seen in Slow Food, which has influenced the Slow City movement with the goal of sustainable urban land use ${ }^{96}$. Additionally, personal and social choices, such as a vegetarian diet, have sweeping implications for ecological impacts through land-use change.

4. Acknowledging farmers' ecological knowledge and actions in local food decision-making. Farmers typically have a firm grasp on the most appropriate crops and techniques in their local region; this information could be used to establish guidelines to better understand local agro-ecological conditions and the social ramifications of farm decisions on the surrounding communities.

Overall, then, research must promote a geographic understanding of local food, which incorporates the social and ecological components of the system. This Food Geography will necessarily capture the concept of 'place' in terms of where the crop is produced and the relevant social relations in that community; what crop is appropriate for a given eco-region and consumer market; and how agro-ecological and community sustainability can best be achieved.

\section{References}

1 Reuters. 2009. American Medical Association Passes Resolution Supporting Sustainable Food System. US Newswire, Wednesday, June 17, 5:59 PM EDT.

2 Diamond, A. and Soto, R. 2009. Facts on Direct-to-Consumer Food Marketing: Incorporating Data from the 2007 Census of Agriculture. US Department of Agriculture, Agricultural Marketing Service, Washington, DC.

3 Darby, K., Batte, M.T., Ernst, S., and Roe, B. 2008. Decomposing local: a conjoint analysis. American Agricultural Economics Association 90:476-486.

4 Hendrickson, J. 1996. Energy use in the U.S. food system: a summary of existing research and analysis. Center for Integrated Agriculture Systems, University of WisconsinMadison. Available at Web site http://www.cias.wisc.edu/wpcontent/uploads/2009/07/energyuse.pdf (accessed 16 March 2010).

5 Allen, P. and Hinrichs, C. 2007. Buying into 'Buy local': engagement of United States local food initiatives. In D. Maye, L. Holloway, and M. Kneafsey (eds). Alternative
Food Geographies: Representation and Practice. Elsevier, Oxford, UK. p. 255-272.

6 Peters, C.J., Bills, N.L., Wilkins, J.L., and Fick, G.W. 2008. Foodshed analysis and its relevance to sustainability. Renewable Agriculture and Food Systems 24:1-7.

7 Duram, L. 2010. Geography. In World Book Encyclopedia. World Book Inc., Chicago IL. Availabe at Web site www. worldbook.com (accessed 23 July 2009).

8 Allen, P. 2008. Mining for justice in the food system: perceptions, practices and possibilities. Journal of Agriculture and Human Values 25:157-161.

9 DuPuis, M.E. and Goodman, D. 2005. Should we go home to eat?: toward a reflexive politics of localism. Journal of Rural Studies 21:359-371.

10 Anderson, M.D. 2008. Rights-based food systems and the goals of food systems reform. Journal of Agriculture and Human Value 25:593-698.

11 Hassanein, N. 2003. Practicing food democracy: a pragmatic politics of transformation. Journal of Rural Studies 19:77-86.

12 Feenstra, G. 1997. Local food systems and sustainable communities. American Journal of Alternative Agriculture 12(1):28-36.

13 Hinrichs, C.C. 2002. The practice and politics of food system localization. Journal of Rural Studies 19(1):33-45.

14 Kloppenburg, J., Hendrickson, J., and Stevenson, G.W. 1996. Coming into the foodshed. Agriculture and Human Values 13(3):33-42.

15 Murdoch, J., Marsden, T., and Banks, J. 2000. Quality, nature, and embeddedness: Some theoretical considerations in the context of the food sector. Economic Geography 76(2): 107-125.

16 Winter, M. 2003. Embeddedness, the new food economy and defensive localism. Journal of Rural Studies 19(1):23-32.

17 Clancy, K. 1997. Reconnecting farmers and citizens in the food system. In W. Lockeretz (ed.). Visions of American Agriculture. Iowa State University, Ames, IA.

18 Lyson, T.A. 2000. Moving toward civic agriculture. Choices: The Magazine of Food, Farm and Resource Issues 3:42-45.

19 Delind, L. 2002. Place, work and civic agriculture: common fields for cultivation. Agriculture and Human Values 19: 217-224.

20 Duram, L.A. 2005. Good Growing: Why Organic Farming Works. University of Nebraska Press, Lincoln, NE.

21 Follett, J.R. 2009. Choosing a food future: differentiating among alternative food options. Journal of Agricultural and Environmental Ethics 22:31-51.

22 Selfa, T. and Qazi, J. 2005. Place, taste, or face to face? Understanding producer-consumer networks in 'local' food systems in Washington State. Agriculture and Human Values 22(4):451-464.

23 Marsden, T. and Smith, E. 2005. Ecological entrepreneurship: sustainable development in local communities through quality food production and local branding. Geoforum 36:440-451.

24 Sage, C. 2003. Social embeddedness and relations of regard: alternative 'Good Food' networks in South-West Ireland. Journal of Rural Studies 19:47-60.

25 Lobb, A.E. and Mazzocchi, M. 2007. Domestically produced food: consumer perceptions of origin, safety and the issue of trust. Food Economics 4:3-12.

26 Fonte, M. 2008. Knowledge, food and place. A way of producing, a way of knowing. Sociologia Ruralis 3rd Series 48:200-222. 
27 Morris, C. and Buller, H. 2003. The local food sector: a preliminary assessment of its impact in Gloucestershire. British Food Journal 105(8):559-566.

28 Smeding, F. and Joenje, W. 1999. Farm-nature plan: landscape ecology based farm planning. Landscape and Urban Planning 46:109-115.

29 Boody, G., Vondracek, B., Andow, D.A., Krinke, M., Westra, J., Zimmerman, J., and Welle, P. 2005. Multifunctional agriculture in the United States. BioScience 55: 27-38.

30 Mäder, P., Fließbach, A., Dubois, D., Gunst, L., Fried, P., and Niggli, U. 2002. Soil fertility and biodiversity in organic farming. Science 296:1694-1697.

31 Henderson, E. 2000. Rebuilding local food systems from the grass-roots up. In F. Magdoff, J. Foster, and F. Buttel (eds). Hungry for Profit: The Agribusiness Threat to Farmers, Food and the Environment. Monthly Review Press, New York. p. 175-188.

32 Horrigan, L., Lawrence, R.S., and Walker, P. 2002. How sustainable agriculture can address the environmental and human health harms of industrial agriculture. Environmental Health Perspectives 110(5):445-456.

33 Smithers, J., Lamarche, J., and Joseph, A.E. 2008. Unpacking the terms of engagement with local food at the farmers' market: Insights from Ontario. Journal of Rural Studies 24(3):337-350.

34 Pirog, R. 2004. Food miles and consumer perceptions of locally grown foods. In Society for Nutrition Education Conference, Salt Lake City, Utah, 17-21 July 2004.

35 The Hartman Group. 2008. Consumer Understanding of Buying Local. Bellevue, WA.

36 Wilson, E.O. 1992. The Diversity of Life. W.W. Norton, New York.

37 Bengtsson, J., Ahnstrom, J., and Weibull, A. 2005. The effects of organic agriculture on biodiversity and abundance: a metaanalysis. Journal of Applied Ecology 42:261-269.

38 Brush, S.B. 1989. Rethinking crop genetic resource conservation. Conservation Biology 3:1-11.

39 Goland, C. and Bauer, S. 2004. When the apple falls close to the tree: Local food systems and the preservation of diversity. Renewable Agriculture and Food Systems 19:228-236.

40 Allan, J.A. 1998. Virtual water: a strategic resource global solutions to regional deficits. Ground Water 36(4):545-546.

41 Chapagain, A.K. and Hoekstra, A.Y. 2004. Water Footprints of Nations. Value of Water Research Report Series of UNESCO-IHE, No. 16. Delft, Netherlands.

42 US Department of Agriculture, Economic Research Service. 2004. Briefing rooms: irrigation and water use. US Department of Agriculture, Economic Research Service, Washington, DC. Available at Web site http://www.ers.usda. gov/Briefing/WaterUse/ (accessed 16 March 2010).

43 Pimentel, D., Berger, B., Filiberto, D., Newton, M., Wolfe, B., Karabinakis, B., Clark, S., Poon, E., Albert, E., and Nandagopal, S. 2004. Water resources: agricultural and environmental issues. BioScience 54:10909-10918.

44 Shoemaker, R., McGranahan, D., and McBride, B. 2006. Agriculture and rural communities are resilient to high energy costs: rising energy prices may prompt farmers and rural residents to make tradeoffs in their production practices and daily lives. Amber Waves 4(2):18-21.

45 Hellegers, P., Ziberman, D., Seduto, P., and McCornick, P. 2008. Interaction between water, energy, food, and environment: evolving perspectives and policy issues. Water Policy 10(1):1-10.

46 Playan, E. and Mateos, L. 2006. Modernization and optimization of irrigation systems to increase water productivity. Agricultural Water Management 80:100-116.

47 Urban, M.A. 2005. Values and ethical beliefs regarding agricultural drainage in Central Illinois, USA. Society and Natural Resources 18:173-189.

48 US Department of Agriculture, Natural Resources Conservation Service. 2009. Alternative crops. Available at Web site http://plants.usda.gov/alt_crops.html (assessed 20 July 2009).

49 Gliessman, S.R. 2006. Agroecology: The Ecology of Sustainable Food Systems. 2nd ed. CRC, Boca Rotan, FL.

50 Diver, S. 2000. Organic Greenhouse Vegetable Production: Horticulture Systems Guide. ATTRA Publication No. IP078. Available at Web site http://attra.ncat.org/attra-pub/PDF/ ghveg.pdf (accessed 16 March 2010).

51 Solomon, S., Qin, D., Manning, M., Chen, Z., Marquis, M., Averyt, K.B., Tignor, M., and Miller, H.L. (eds). 2007. Climate Change 2007. The Physical Science Basis. Contribution of Working Group I to the Fourth Assessment Report of the Intergovernmental Panel on Climate Change. Cambridge University Press, New York.

52 Pew Center on Global Climate Change. 2009. Agriculture overview. Available at Web site http://www.pewclimate.org/ technology/overview/agriculture (accessed 16 March 2010).

53 US Department of Agriculture, Office of the Chief Economist and Economic Research Service. 2009. A Preliminary Analysis of the Effects of HR 2454 on U.S. Agriculture. US Department of Agriculture, Washington, DC.

54 US Department of Agriculture, Economic Research Service. 2009. Global Climate Change: Background. Available at Web site http://www.ers.usda.gov/Briefing/GlobalClimate/ Background.htm (accessed 16 March 2010).

55 Puckett, L.J. 2008. Nonpoint and Point Sources of Nitrogen in Major Watersheds of the United States. US Geological Survey. Water-Resources Investigations Report 94-4001. Available at Web site http://pubs.usgs.gov/wri/wri944001/ wri944001.html (accessed 16 March 2010).

56 US Department of Agriculture, Economic Research Service. 2008. U.S. Fertilizer Use and Price. Data set. Available at Web site http://www.ers.usda.gov/Data/FertilizerUse/ (accessed 16 March 2010).

57 Schoof, J.T. and Therrell, M. 2009. Climate change. In L. Duram (ed.). The Encyclopedia of Organic, Sustainable, and Local Food. Praeger/ABC-CLIO, Santa Barbara, CA/ Oxford, England. p. 82-84.

58 Robertson, G.P., Paul, E.A., and Harwood, R.A. 2000. Greenhouse gases in intensive agriculture: contributions of individual gases to the radiative forcing of the atmosphere. Science 289:1922-1925.

59 Weber, C.L. and Matthews, S.H. 2008. Food-miles and the relative climate impacts of food choices in the United States. Environmental Science and Technology 42(10):3508-3513.

60 Battisti, D.S. and Naylor, R. 2009. Historical warnings of future food insecurity with unprecedented seasonal heat. Science 323:240-244.

61 US Climate Change Science Program. 2008. The Effects of Climate Change on Agriculture, Land Resources, Water Resources, and Biodiversity in the United States. US Department of Agriculture, Washington, DC. 
62 Marris, E. 2004. Climate modellers go local to target California's politicians. Nature 430(7002):818.

63 Hayhoea, K., Cayanc, D., Fieldd, C.B., Frumhoffe, P.C., Maurerf, E.P., Millerg, N.L., Moserh, S.C., Schneideri, S.H., Cahilld, K.N., Clelandd, E.E., Daleg, L., Drapekj, R., Hanemannk, R.M., Kalksteinl, L.S., Lenihanj, J., Lunchd, C.K., Neilsonj, R.P., Sheridanm, S.C., and Vervillee, J.H. 2004. Emissions pathways, climate change, and impacts on California. Proceedings of the National Academy of Sciences of the USA 101(34):12422-12427.

64 Schoof, J.T. 2009. Historical and projected changes in the length of the frost-free season. In S.C. Pryor (ed.). Understanding Climate Change: Climate Variability, Predictability, and Change in the Midwestern United States. Indiana University Press, Bloomington, IN. p. 42-54.

65 Coley, D., Howard, M., and Winters, M. 2009. Local food, food miles and carbon emissions: a comparison of farm shop and mass distribution approaches. Food Policy 34:150-155.

66 Edwards-Jones, G., Milà i Canals, L., Hounsome, N., Truninger, M., Koerber, G., Hounsome, B., Cross, P., York, E.H., Hospido, A., Plassmann, K., Harris, I.M., Edwards, R.T., Day, G.A.S., Deri Tomos, A., Cowell, S.J., and Jones, D.L. 2008. Testing the assertion that 'local food is best': the challenges of an evidence-based approach. Trends in Food Science and Technology 19:265-274.

67 Jones, A. 2002. An environmental assessment of food supply chains: a case study on dessert apples. Environmental Assessment 30:560-576.

68 Pirog, R. and Benjamin, A. 2003. Checking the Food Odometer: Comparing Food Miles for Local Versus Conventional Produce Sales to Iowa Institutions. Leopold Center for Sustainable Agriculture, Ames, IA.

69 Pimentel, D., Williamson, S., Alexander, C.E., GonzalezPagan, O., Kontak, C., and Mulkey, S.E. 2008. Reducing energy inputs in the US food system. Human Ecology 36: 459-471.

70 Sirieix, L., Grolleau, G., and Schaer, B. 2008. Do consumers care about food miles? An empirical analysis in France. International Journal of Consumer Studies 32: 508-515.

71 Blanke, M.M. and Burdick, B. 2005. Food (miles) for thought: energy balance for locally-grown versus imported apple fruit. Environmental Science and Pollution Resource 12:125-127.

72 Hospido, A., Canals, L., MacLaren, S., Truninger, M., Edwards-Jones, G., and Clift, R. 2009. The role of seasonality in lettuce consumption: a case study of environmental and social aspects. International Journal of Life Cycle Assessment 14:381-391.

73 Saunders, C., Barber, A. and Taylor, G. 2006. Food Miles: Comparative Energy/Emissions Performance of New Zealand's Agriculture Industry. Report 285. Agribusiness and Economics Research Unit. Lincoln University, New Zealand. Available at Web site http:www.lincoln.ac.nz/ story9430.html (accessed 24 July 2009).

74 Wilson, T. 2007. The 'Food Miles' Fallacy. Institute of Public Affairs, Australia. Available at Web site http://www.ipa.org.au (accessed 23 July 2009).

75 Foster, C., Green, K., Bleda, M., Dewick, P., Evans, B., Flynn, A., and Mylan, J. 2006. Environmental Impacts of Food Production and Consumption: a Report to the Department of
Environment, Food and Rural Affairs. Manchester Business School, DEFRA, London.

76 Pretty, J.N., Ball, A.S., Lang, T., and Morison, J.I.L. 2005. Farm costs and food miles: an assessment of the full cost of the UK weekly food basket. Food Policy 30:1-19.

77 Schlich, E.H. and Fleissner, U. 2005. The ecology of scale: assessment of regional energy turnover and comparison with global food. International Journal of Life Cycle Assessment 10(3):219-223.

78 Jungbluth, N. and Demmeler, M. 2005. Letters to the Editor. International Journal of Life Cycle Assessment 10(3): 168-170.

79 LaTrobe, H.L. and Acott, T.G. 2000. Localising the global food system. International Journal of Sustainable Development and World Ecology 7:309-320.

80 Jarosz, L. 2008. The city in the country: growing alternative food networks in metropolitan areas. Journal of Rural Studies 24:231-244.

81 DeLind, L.B. and Bingen, J. 2008. Place and civic culture: re-thinking the context for local agriculture. Journal of Agricultural and Environmental Ethics 21:127-151.

82 Reganold, J.P., Glover, J.D., Andrews, P.K., and Hinman, H.R. 2001. Sustainability of three apple production systems. Nature 410:929-930.

83 Hill, H. 2009. Comparing Energy Use in Conventional and Organic Cropping Systems. ATTRA. National Sustainable Agriculture Information Service. Available at Web site http://www.attra.ncat.org/attra-pub/PDF/croppingsystems.pdf (accessed 9 October 2009)

84 Flegal, K.M., Carroll, M.D., Ogden, C.L., and Johnson, C.L. 2002. Prevalence and trends in obesity among U.S. adults, 1999-2000. Journal of the American Medical Association 288(14):1723-1727.

85 Carlsson-Kanyama, A., Ekstrom, M.P., and Shanahan, H. 2003. Food and life cycle energy inputs: consequences of diet and ways to increase efficiency. Ecological Economics 44:293-307.

86 Pimentel, D. and Pimentel, M. 1996. Food, Energy and Society. Colorado University Press, Niwot, CO.

87 Reijnders, L. and Soret, S. 2003. Quantification of the environmental impact of different dietary protein choices. American Journal of Clinical Nutrition 78(3):664S-668S.

88 Pimentel, D. 2006. Impacts of Organic Farming on the Efficiency of Energy Use in Agriculture: State of Science Report. Organic Center, Bolder, CO.

89 Steinfeld, H., Gerber, P., Wassenaar, T., Castel, V., Rosales, M., and de Haan, C. 2006. Livestock's Long Showdown: Environmental Issues and Options. United Nation's Food and Agriculture Organisation, Rome, Italy. Available at Web site ftp://ftp.fao.org/docrep/fao/010/a0701e/A0701E00.pdf (accessed 8 February 2010).

90 Peters, C.J., Bills, N.L., Lembo, A.J., Wilkins, J.L., and Fick, G.W. 2008. Mapping potential foodsheds in New York State: a spatial model for evaluating the capacity to localize food production. Renewable Agriculture and Food Systems 24:72-84.

91 Timmons, D., Wang, Q., and Lass, D. 2008. Local foods: estimating capacity. Journal of Extension 46:1-11.

92 Howden, S.M., Soussana, J.F., Tubiello, F.N., Chhetri, N., Dunlop, M., and Meinke, H. 2007. Adapting agriculture to climate change. Proceedings of the National Academy of Sciences of the USA 104:19691-19696. 
93 Francis, C.A., Lieblein, G., Breland, T.A., and Salomonsson, L. 2008. Transdisciplinary research for a sustainable agriculture and food sector. Agronomy Journal 100:771-776.

94 King, C.A. 2008. Community resilience and contemporary agri-ecological systems: reconnecting people and food, and people with people. System Research and Behavioral Science 25:111-124.
95 Duram, L.A. 2009. The Encyclopedia of Organic, Sustainable, and Local Food. Praeger/ABC-CLIO, Santa Barbara, CA/ Oxford, England.

96 Mayer, H. and Knox, P.L. 2006. Slow cities: sustainable places in a fast world. Journal of Urban Affairs 4th Series 28:321-334. 